\title{
Microbial Quality of Raw and Ready-To-Eat Mung Bean Sprouts Produced in Italy
}

\author{
Iacumin Lucilla, Ginaldi Federica, Andyanto Debbie and Giuseppe Comi* \\ Department of Agricultural and Food, University of Udine, Italy
}

Submission: April 04, 2017; Published: May 30, 2017

*Corresponding author: Giuseppe Comi, Department of Agricultural, Food, Environmental and Animal Science, University of Udine, Italy, Tel: +390432558129; Fax: +390432558130; Email:giuseppe.comi@uniud.it

\begin{abstract}
The aim of this study was to determine the microbial quality of mung bean sprouts produced in Italy. In particular, the presence of pathogenic microorganisms (Shiga Toxin Escherichia coli, Salmonella spp. and Listeria monocytogenes), enterobacteriaceae, total viable count (TVC) and E. coli were determined. The study covered five years of sprouts production. The results demonstrated that no pathogenic microorganisms were present and the total microbial load was less than $6 \log \mathrm{CFU} / \mathrm{g}$. Consequently, up to now the mung bean sprouts produced in Italy seem to be acceptable for the consumption. Despite these encouraging results, the producer attention to the hygienic quality should never be reduced in order to obtain safe mung bean sprouts.
\end{abstract}

Keywords: Mung bean sprouts; Microbial quality; STEC; Salmonella spp; Listeria monocytogenes

\section{Introduction}

Recently mung bean sprouts, originated in Far East areas, have been wide spread to the western world. They are vegetable produced by seeds sprouting and considered fashionable and important for human diet providing health benefits, because they are important source of proteins, vitamins, minerals and fibers $[1,2]$. The production technology consists in the growth of mung bean sprouts under environmentally controlled conditions. Indeed the seeds are sprouted at $22-24{ }^{\circ} \mathrm{C}$ and $95 \%$ H.R. (relative humidity) for three-four days [3,4]. Seeds are usually contaminated by high microbial loads, including yeasts, Pseudomonads, enterobacteria, and lactic acid bacteria. These microorganisms can then increase at level of 1010CFU/g, due to both the environmental conditions of the sprouting phase and the rich nutritional characteristics of the substrate [510]. Pathogenic microorganisms can also contaminate them, either as primary contamination (while growing in and during harvest) or secondary contamination (during washing, slicing, soaking, packaging and preparation) [8]. Usually, the pathogens' contamination of sprouts comes from the seeds. It is largely recognized that the sprout-associated outbreaks occurred due to seeds contaminated with pathogenic microorganisms $[3,11]$ rather than post-production contamination [12]. The load of pathogenic microorganisms increases because of the high volumes of water and sprouting temperature used during sprout production, especially in systems where sprouts are exposed to a common "water bath" and frequently or continuously mixed, such as in a rotary drum [12].

For these reasons sprouted seeds, have been implicated in a large number of serious outbreaks caused by Salmonella spp. and Shiga toxin-producing Escherichia coli. In particular, S. Bareilly in United kingdom [13], S. Newport in Germany and Netherlands [14] and S. enteritidis in the United States [15] were responsible for outbreaks associated with bean sprouts consumption. Salmonella spp. and Escherichia coli 0157:H7 are the most frequently associated causative agents of outbreaks caused by Alfalfa and mung bean sprouts consumption in North America [16-21] clearly indicating that mung bean sprouts constitute a significant food safety risk [22].

Furthermore also other shiga toxin producing Escherichia coli (STEC) produced various major outbreak associated with consumption of sprouted-fenugreek seeds in Northern Germany together with 14 EU countries, in USA and Canada $[18,23,24]$. Considering sprouts pose a very complex challenge to bacterial pathogen enrichment, the aim of this work was to evaluate the microbial quality of mung bean sprouts produced and sold in Italy.

\section{Material and Methods}

Mung beans sprouts were collected from different Italian retailers. Six hundred samples (10 samples per month) have 
been analyzed during 5 years, from January/1 $1^{\text {st }} 2012$ to December $/ 31^{\text {st }} 2016$. They were sampled and analyzed on the $3^{\text {rd }}$ day out of the 5 days of shelf-life. The storage during shelflife was performed maintaining temperature $<7^{\circ} \mathrm{C}$. Analyses were conducted in duplicate on three biological replicates per each sampling point. The sample of $10 \mathrm{~g}$ of the sprouts was serially diluted with saline-peptone water $(8 \mathrm{~g} / \mathrm{l} \mathrm{NaCl}, 1 \mathrm{~g} / \mathrm{l}$ bacteriological peptone Oxoid, Italy) in stomacher bags. An aliquot of 1 or $0.1 \mathrm{ml}$ of each serial dilution was plated onto agar for counts of different groups of microorganisms:

i) Total Mesophilic Viable Count (TVC) was evaluated on Plate Count Agar (Oxoid, Italy) incubated at $30{ }^{\circ} \mathrm{C}$ for 48 $72 \mathrm{~h}$.

ii) Total coliforms and Escherichia coli were counted on Violet Red Bile Lactose Agar (VRBLA) (Oxoid, Italy) incubated for $24 \mathrm{~h}$ at $37^{\circ} \mathrm{C}$ at $44^{\circ} \mathrm{C}$, respectively. iii) Salmonella spp. was evaluated by the ISO (6579-1 2002 Cor.1:2004 Microbiology of food and animal feeding stuffs - Horizontal method for the detection of Salmonella spp.) method.

iv) Listeria monocytogenes by ISO (11290-1,2: 1996 Adm.1:2004. Microbiology of food and animal feeding stuffs- Horizontal method for the detection of Listeria monocytogenes) method.

v) STEC by CEN ISO TS 13136 (Comission Regulation EU n. 209/13 - 11/03/2013 amending regulation EC 2073/2005 as regards microbiological criteria for sprouts and the sampling rules for poultry carcases and fresh poultry meat - Official J. European Union L 68/19) method. Statistical analysis of the obtained data was performed by one-way analysis of variance. The averages of the microbial loads were compared with Tukey's honest significance test using the Statistical Graphics software package $(\mathrm{p}<0.05)$.

\section{Results and Discussion}

Table 1: Microbial quality of mung bean sprouts (Data Log CFU/g).

\begin{tabular}{|c|c|c|c|c|c|}
\hline \multirow{2}{*}{ Microbial Group } & \multicolumn{5}{|c|}{ Year of Sampling** } \\
\hline & 2012 & 2013 & 2014 & 2015 & 2016 \\
\hline Total viable count & $5.5 \pm 0.3$ & $5.2 \pm 1.1$ & $5.3 \pm 0.8$ & $5.1 \pm 1.1$ & $5.2 \pm 1.0$ \\
\hline Total coliforms & $3.4 \pm 0.8$ & $3.3 \pm 1.1$ & $3.2 \pm 0.5$ & $3.5 \pm 0.4$ & $<.1 \pm 0.9$ \\
\hline Escherichia coli & $<1$ & $<1$ & $<1$ & Absence & Absence \\
\hline$*$ Salmonella spp. & Absence & Absence & Absence & Absence & Absence \\
\hline$*$ *.monocytogenes & Absence & Absence & Absence & Absence & Absence \\
\hline *STEC & Absence & Absence & Absence & \\
\hline
\end{tabular}

Legend: STEC: Shiga Toxin E. coli; *: Absence in 25g; **: no significative difference among the years of investigation $(p>0.05)$.

The microbial loads of the investigated sprouts produced and sold in Italy were lower than the ones produced and sold in other parts of Europe or the World [3-5,25,26]. As shown, TVC concentration was lower than $6 \log \mathrm{UFC} / \mathrm{g}$, whereas enterobacteriaceae were lower than $4 \log \mathrm{UFC} / \mathrm{g}$ (Table 1) and no significant difference were observed during the 5 years monitored ( $p>0.05)$. Mung bean sprouts were grown in cellars from seeds placed in plastic washtubs, incubated at $22{ }^{\circ} \mathrm{C}$ under $90 \%$ R.H. and watered each 5 hours.

The abundance of nutrient from sprouting seeds, the temperature of growing and R.H. of the sellers were the ideal environmental conditions for microbial growth $[3,4]$. In addition, seeds may contain high microbial loads $>6$ log $\mathrm{CFU} / \mathrm{g}$ ), represented by environmental microorganisms, such as enterobacteria, pseudomonads, lactic acid bacteria and yeast, that can rapidly grow $[5,25,27]$ and reach high concentration levels $(>1010 \mathrm{CFU} / \mathrm{g}$ ) $[5-7,26,27]$. TVC of seeds used for the production was always $<104 \mathrm{CFU} / \mathrm{g}$. This value was lower than the concentration revealed by other authors, who found in commercial seeds values higher than 104CFU/g $[26,28-30]$

A possible explanation for these findings could be attributed at both the use of sanitized production plants and the drinking water for watering. The value of TVC concentration did not allow prolonging the shelf-life of the investigated sprouts up to 5 days. However, also in case of a TVC exceeding $7 \log \mathrm{CFU} / \mathrm{g}$, the appearance of sprouts are not negatively affected [4]. In addition, no pathogenic microorganisms were detected in the investigated sprouts, in fact Salmonella spp., Listeria spp. and STEC resulted always absent/25g. Pathogenic bacteria usually contaminate seeds, which are generally recognized as the main source of bacterial pathogens in most sprout-related outbreaks reported by the National Advisory Committee on Microbiological Criteria for Foods [11] and by various authors $[3,4,31]$.

In this case the control of each lot of seeds, used to produce the investigated sprouts, never demonstrated the presenteither of STEC or Salmonella spp. and L. monocytogenes. According to 
Commission Regulation (EU) No. 209/2013. Italian producers control the seeds and the sprouts before the production and sale for the presence of STEC. Up to now, STEC were never found in all the lots of mung bean seeds and consequently also in the sprouts made with those seeds. Yet, the absence of the above three pathogenic species has been demonstrated since 1982, when different Italian sprout producers started their activity.

\section{Conclusion}

This study provides information on the hygienic quality and microbial status of mung beans sprouts produced in Italy. The microbial loads were lower than the ones observed in seeds and sprouts produced in other countries. In particular the pathogenic microorganisms, responsible of outbreaks, as demonstrated in the last ten years $[18,23,24]$ were never present. Despite these encouraging results, the attention to the hygienic quality should never be reduced and the Italian producers know the importance to apply the Good Manufacturing and Hygienic Practices in order to produce and sell safe mung bean sprouts. In particular, to minimize microbial contamination of sprouts prior to consumption, the initial microbial load and the presence of pathogenic microorganisms of seeds must be controlled.

\section{Acknowledgement}

The authors thank Azienda Agricola Amilcare Adami, Via Dorno 109, 27026 Garlasco (PV) Italy for the suggestion about the mung bean sprouts technology.

\section{References}

1. Kuo YH, Rozan P, Lambein F, Frías J, Vidal-Valverde C (2004) Effects of different germination conditions on the contents of free protein and non-protein amino acids of commercial legumes. Food Chem 86(2004): 537-545

2. Martínez-Villaluenga C, Gulewicz P, Pérez A, Frías J, Vidal-Valverde C (2006) Influence of lupin (Lupinus luteus L. cv. 4492 and Lupinus angustifolius L. var. Zapaton) and fenugreek (Trigonella foenumgraecum L.) germination on microbial population and biogenic amines. J Agric Food Chem 54(19): 7391-7398.

3. Peles F, Győri Z, Bácskai T, Szabó ZS, Murvai M, et al. (2012) Microbiological quality of organic wheat grains and sprout. Analele Univers din Orad Facl Prtcia Medi (18): 53-60.

4. Taormina PJ, Beuchat LR, Slutsker L (1999) Infections associated with eating seed sprouts: an international concern. Emerging Inf Disease 5(5): 626-634.

5. Randazzo CL, Scifò GO, Tomaselli F, Caggia C (2009) Polyphasic characterization of bacterial community in fresh cut salads. Int J Food Microbiol 128(3): 484-490

6. Ghandi M, Matthews KR (2003) Efficacy of chlorine and calcinated calcium treatment of alfalfa seeds and sprouts to eliminate Salmonella. Int J Food Microbiol 87(3): 301-306.

7. Peńas E, Gómez R, Frías J, Vidal-Valverde C (2008) Application of high pressure treatment on alfalfa (Medicago sativa) and mung bean (Vigna radiata) seeds to enhance the microbial safety of their sprouts. Food Control 19(7): 698-705.
8. Harris LJ, Farber JN, Beuchat LR, Parish ME, Suslow TV, et al. (2003) Outbreaks associated with fresh produce: Incidence, growth, and survival of pathogens in fresh and fresh cut produce. Compr Rev Food Sci F 2(1): 1-64.

9. Zheng Q Mikšs-Krajnik M, D’Souza C, Yang Y, Heo DJ, et al. (2015) Growth of healthy and sanitizer-injured Salmonella cells on mung bean sprouts in different commercial enrichment broths. Food Microbiol 52: 159-168.

10.Zheng Q Mikšs-Krajnik M, D’Souza C, Yang Y, Heo DJ, et al. (2016) Evaluation of real-time PCR coupled with immunomagnetic separation or centrifugation for the detection of healthy and sanitizer-injured Salmonella spp. on mung bean sprouts. Int J Food Microbiol 222: 4855.

11.(1999) Microbiological safety evaluations and recommendations on sprouted seeds. NACMCF National Advisory Committee on Microbiological Criteria for Food. Int J Food Microbiol 52(3): 123-153.

12. Xiao Z, Nou X, Luo Y, Wang Q (2014) Comparison of the growth of Escherichia coli 0157: H7 and 0104: H4 during sprouting and microgreen production from contaminated radish seeds. Food Microbio 44: 60-63.

13. Cleary P, Browning L, Coia J, Cowden J, Fox A, et al. (2010) A food borne outbreak of Salmonella Bareilly in the United Kingdom. Euro Surveill 15(48): 19732.

14. Bayer C, Bernard H, Prager R, Rabsch W, Hiller P, et al. (2014) An outbreak of Salmonella Newport associated with mung bean sprouts in Germany and the Netherlands, October to November 2011. Euro Surveill 19(1): 20665.

15. FDA (2014) FDA Investigates Multistate Outbreak of Salmonella Enteritidis Linked to Mung Bean Sprouts Produced by Wonton Foods Inc. of New York US food \& drug adminstion. USA.

16. CDC (2012) Escherichia coli. Centers for Disease Control and Preventio, USA.

17. Fett WF (2005) Interventions to ensure the microbiological safety of sprouts. In: Sapers GM (Eds.), Microbiology of fruit and vegetables, CRC Press, USA, pp. 187-210.

18. Health Canada (2012) Risk associated with sprouts. Canada.

19. Baranzoni GM, Fratamico PM, Rubio F, Glaze T, Bagi LK, et al. (2014) Detection and isolation of Shiga toxin-producing Escherichia coli (STEC) 0104 from sprouts. Int J Food Microbiol 173: 99-104.

20. Baker CA, Rubinelli PM, Hong PS, Carbonero F, Ricke SC, et al. (2016) Shiga toxin-producing Escherichia coli in food: Incidence, ecology, and detection strategies. Food Control 59: 407-419.

21. Margot H, Tasara T, Zwietering MH, Joosten H, Stephan R (2016) Effects of different media on the enrichment of low numbers of Shiga toxin-producing Escherichia coli in mung bean sprouts and on the development of the sprout microbiome. Int J Food Microbiol 232: 2634.

22. Gómez-ACA, Rangel-Vargas E, Bautista-De LH, Vázquez-Barrios EM, Gordillo-Martínez AJ, et al. (2013) Behavior of enteroaggregative Escherichia coli, non-0157-shiga toxin-producing E. coli, enteroinvasive E. coli, enteropathogenic E. coli and enterotoxigenic E. coli strains on mung bean seeds and sprout. Int J Food Microbiol 166(3): 364-368.

23. Buchholz U (2011) German outbreak of Escherichia coli 0104:H4 associated with sprouts. N Engl J Med 365(19): 1763-1770.

24. EFSA (2012) Scientific opinion on the risk posed by Shiga toxinproducing Escherichia coli (STEC) and other pathogenic bacteria in seeds and sprouted seeds. EFSA J 9(11): 1-101.

25. Robertson LJ, Johannessen GS, Gjerde BK, Loncarevic S (2002) Microbiological analysis of seed sprouts in Norway. Int J Food Microbiol 
75(1-2): 119-126.

26. Patterson JE, Woodburn MJ (1980) Klebsiella and other bacteria on alfalfa and bean sprouts at the retail level. J Food Sci 45: 492-495.

27. Prokopowich D, Blank G (1991) Microbiological evaluation of vegetable sprouts and seeds. J Food Protect 54(7): 560-562.

This work is licensed under Creative Commons Attribution 4.0 License

DOI: $10.19080 /$ NFSIJ.2017.03.555601
28. Andrews WH, Wilson CR, Poelma PL, Romero A, Mislivec PB (1979) Bacteriological survey of sixty health foods. Appl Environ Microbiology 37(3): 559-566

29. Andrews WH, Mislivec PB, Wilson CR, Bruce VR, Polema PL, et al. (1982) Microbial hazards associated with bean sprouting. J Ass Off Anal Chemists 65(2): 241-248.

\section{Your next submission with Juniper Publishers} will reach you the below assets

- Quality Editorial service

- Swift Peer Review

- Reprints availability

- E-prints Service

- Manuscript Podcast for convenient understanding

- Global attainment for your research

- Manuscript accessibility in different formats ( Pdf, E-pub, Full Text, Audio)

- Unceasing customer service

Track the below URL for one-step submission https://juniperpublishers.com/online-submission.php 